\title{
Histological Changes of the Ovary of Adult Mice Exposed Prenatally to Flunitrazepam
}

\author{
Cambios Histológicos del Ovario de Ratones Adultos Expuestos Prenatalmente a Flunitrazepam
}

Ana Julia Aguirre -Samudio; Graciela de la Fuente-Juárez; Amalia Márquez-Orozco; María Cristina Márquez-Orozco

AGUIRRE-SAMUdiO, A. J.; DE LA FUENTE-JUÁREZ, G.; MÁRQUEZ-OROZCO, A. \& MÁRQUEZ-OROZCO, M. C. Histological changes of the ovary of adult mice exposed prenatally to flunitrazepam. Int. J. Morphol., 24(4):651-658, 2006.

SUMMARY: Flunitrazepam (FNZ) is a minor tranquillizer involving allosteric modulation of the GABA receptor complex. It is a ligand of the peripheral benzodiazepine receptor (PBR) that participates in cholesterol transport in steroidogenic organs. The purpose was to investigate whether a single oral dose of FNZ of $2.5 \mathrm{mg} / \mathrm{kg}$ of body weight (bw), administered on day 6 of gestation, alters the structure of the adult ovary of mouse offsprings at 2 months of age. The mouse offsprings of the in utero FNZ-treated group and those of the control group (C) were killed. Ovaries were obtained in early estrous, fixed in Zenker solution, and processed by routine histological techniques. Serial sections were observed under light microscopy to determine the characteristics and quantity of follicles in different stages of development and of the corpus luteum. The ovarian tissues from the FNZ group depicted a great staining affinity, enlarged nuclei with abundant heterochromatin clumps. The quantity of primordial, primary and secondary normal follicles in the FNZ group decreased significantly $(\mathrm{p}<0.01)$. The number of primary atretic follicles increased $(\mathrm{p}<0.01)$ and the secondary ones remained constant as in group C. Histological changes and statistical data suggest that FNZ produces long-lasting epigenetic or genotoxic effects in follicular and corpus luteum cells of the ovary of prenatally FNZ-treated mice.

KEY WORDS: Benzodiazepine; Flunitrazepam; Atretic follicles; Corpus luteum; Prenatal exposure.

\section{INTRODUCTION}

Flunitrazepam (FNZ) is a benzodiazepine (BDZ) producing sedative, anxiolytic, hypnotic, anticonvulsant, and muscle relaxant effects in humans and rodents (File, 1990). It is also an addiction drug (known as Rohypnol) used alone or in combination with heroine, cocaine, and/ or alcohol, among teenagers and young adults (U.S. Department of Justice, www.usdoj.gov/dea/).

Given their liposolubility, both FNZ and diazepam (DZ) cross the placental barrier (McAllister, 1980; Kanto et al., 1987). With a long half-life (20 h) FNZ is slowly eliminated in pregnant women. It is accumulated in the fetus and the mother and eliminated in the milk. The FNZ fetal blood levels have been found lower than those of other benzodiazepines (Kanto, 1982). The administration of higher than therapeutic $(0.5-3.0 \mathrm{mg})$ doses of BDZ (i.e., 100 to $400 \mathrm{mg}$ ) in pregnant women and rodent females leads to teratogeny. Newborns from mothers with high BDZ levels during delivery show apnea and Apgar test of 5-6 during the first minute (André et al., 1973; Laegreid, 1989). BDZs are agonist ligands of the central benzodiazepinic receptor (CBR), located in the chlorine channels contacting the central nervous system, they are also ligands of the ubiquitous peripheral benzodiazepine receptor (PBR) (Parola et al., 1993; Zisterer \&Willians, 1997). The steroidogenic ovary, testes, and adrenal glands contain PBRs involved in the metabolism and/or transport of cholesterol (Mukhin et al., 1989; Papadopoulos et al., 1991, 1997).

In mice exposed to DZ (2.7 $\mathrm{mg} / \mathrm{kg}$ bw) during gestation (6 to 15 days or 6 to 17 days) histological changes have been observed in the mesencephalon, bone, ovary, testicle, kidney and fetal liver (Márquez-Orozco et al., 1998), bone (De la Fuente-Juárez et al., 1998), ovary (Hernández et al., 1991), testicle (Mata-Santibañez et al., 1993), kidney, and fetal liver (Márquez-Orozco et al., 1984, 1993) have been observed. At present, it is not known whether prenatal FNZ induces changes similar to those caused by DZ. The aim of the present work was to investigate ovary changes and structural characteristics in prenatally FNZ-exposed mice. 


\section{MATERIAL AND METHOD}

Animals and treatment. ICR strain mice from Harlan Sprague Dawley, Indianapolis, were breed in the animal facilities of the Department of Embryology, School of Medicine, U.N.A.M. Females and males were kept separately in polypropylene cages in a conventional environment, and had free access to food and water. Nine virgin females were mated with three experimented males of the same strain and age. The vaginal plug was taken at the start of gestation, and the animals randomly distributed in three groups. The first group, called FNZ group was treated with a single oral $2.5 \mathrm{mg} / \mathrm{kg}$ bw dose of FNZ (Roche®) on gestation day (GD) 6. The second group, the "S" group was given $0.9 \%$ saline solution on GD 6 orally. A third "NT" group was not treated. Spontaneously birth occurred between GD 18 and GD 19 ; the offsprings were placed with non-treated foster mice for nursing, weaned at day 21, and kept for a total of 63 days under the same control conditions.

Histological processing of the ovaries. The early estrous was determined on day 63 in all mouse offsprings. All the females were then decapitated. The ovaries were removed, fixed in Zenker solution, and embedded in Paraplast. Serial sections $(5 \mu \mathrm{m})$ of the medullary area were obtained in each group and stained with hematoxylin-eosin. The sections were observed under light microscopy, evaluating healthy and atretic follicles. According to Jolly et al. (1997), the healthy follicles, all with intact oocytes, were classified in: a) primordial follicles (pf); b) primary or preantral follicles $\left(1^{\circ} \mathrm{F}\right)$, without follicular antrum, c) secondary or antral follicle $\left(2^{\circ} \mathrm{F}\right)$, showing follicular antrum. The atretic follicles were characterized by degenerating oocytes, disorganized granulosa cell layers, folded zona pellucida, partially or completely separated from corona radiata and from the granulosa cells of the oocyte. Apoptotic bodies were common inside and outside the oocytes and in the granulosa cells (Byskov, 1978). The degenerating primordial or primary follicles were termed atretic follicles $\left(\mathrm{A} 1^{\circ} \mathrm{F}\right)$, and those with degeneration in the secondary of Graaf follicles, atretic secondary follicles $\left(\mathrm{A} 2^{\circ} \mathrm{F}\right)$. The number of corpus luteum bodies per ovary was counted, and the total number of luteal and paraluteal cells calculated per square millimeter of ovary, per individual.

Statistical Analysis. The mean \pm SE of each variable was studied in FNZ, S, and NT groups, and the statistical significance determined with Kruskal Wallis and U Mann Whitney tests $(\mathrm{p}<0.05)$.

\section{RESULTS}

Effects of FNZ on ovarian morphology. Ovaries of offsprings treated in utero with FNZ did not present gross morphologic differences compared to those of the control groups. All ovarian sections showed healthy follicles in different developmental stages and atretic follicles, as well as corpus lutei.

The primordial follicles of the FNZ and control groups depicted oocytes with scanty cytoplasm, basophilic inclusion, and flattened granulosa cells, although those in the FNZ group showed greater staining affinity. The granulosa and stroma cells showed an apparent increase of heterochromatin. The primary and secondary healthy follicles of the FNZ group depicted a normal appearance, although with high staining affinity with respect to the control group (Fig. 1). FNZ atretic follicles $\left(\mathrm{A} 1^{\circ} \mathrm{F}\right)$ presented retracted primary oocytes with vacuolated cytoplasm, eccentric nucleoli, clumps of heterochromatin, and an irregular membrane. The zona pellucida was disintegrated in many areas and the granulosa cells were disaggregated. Granulosa cells were observed around the oocytes with piknotic nuclei, the corona radiata cells were detached from the zona pellucida, which was folded. Granulosa layer cells underwent disorganization presenting dispersed macrophages (Fig. 2).

Effects of FNZ on corpus luteum. In ovaries of FNZ, S, and NT groups, polyhedral luteal cells were observed. Greater staining affinity was evident in FNZ luteal and paraluteal cells. Their nuclei showed apparent heterochromatin increase, a prominent nucleolus, cytoplasm inclusions with vacuolar appearance, and poor staining (Fig. 3).

Statistical analysis. The mean number in healthy NT mice were: primordial follicles, $15.8 \pm 1.1$; in the $S$ group, $10.4 \pm 2.1$ $(\mathrm{p}=0.327)$; in the FNZ group, $7.7 \pm 1.25(\mathrm{p}<0.001) . \mathrm{NT}$ primary follicles were $33.4 \pm 1.1$; in the $S$ group, $32.6 \pm 6.8$ $(\mathrm{p}=0.619)$; in FNZ-treated group, $17.5 \pm 1.9(\mathrm{p}<0.001)$. The NT secondary follicles were $8.8 \pm 1.0$; in $S, 10.0 \pm 0.9$ $(\mathrm{p}=0.277)$; in FNZ group, $3.0 \pm 0.6(\mathrm{p}<0.01)$ (Fig. 4A). Atretic follicles were also counted in the control and FNZ group, the mean number of NT primary follicles was $8.8 \pm 1.0$; in the $\mathrm{S}$ group, $10.0 \pm 0.9$ ( $\mathrm{p}=0.563)$; in the FNZ group, 17.8 \pm 2.4 $(\mathrm{p}<0.02)$. The NT secondary atretic follicles were 10.8 \pm 1.3 ; in the $\mathrm{S}$ group, $11.2 \pm 0.5(\mathrm{p}=0.411)$; in the FNZ group, $12.6 \pm 1.9(\mathrm{p}=0.52)$ (Fig. 4B).

Corpus luteum number in NT mice was 7.72 \pm 0.75 ; in the $S$ group, $5.9 \pm 0.8(p=0.112)$; in the FNZ group, $4.8 \pm 0.9$ $(\mathrm{p}<0.02)$. NT granulosa luteal cells population was 
$22.9 \pm 0.57$; in the $\mathrm{S}$ group, $21.7 \pm 0.57(\mathrm{p}=0.097)$; in FNZ

$8.1 \pm 0.4$; in the $\mathrm{S}$ group, $7.2 \pm 0.5$ ( $\mathrm{p}=0.111)$; in the FNZ group, group, 17.6 $\pm 0.6(\mathrm{p}<0.001)$. NT theca luteal cells were

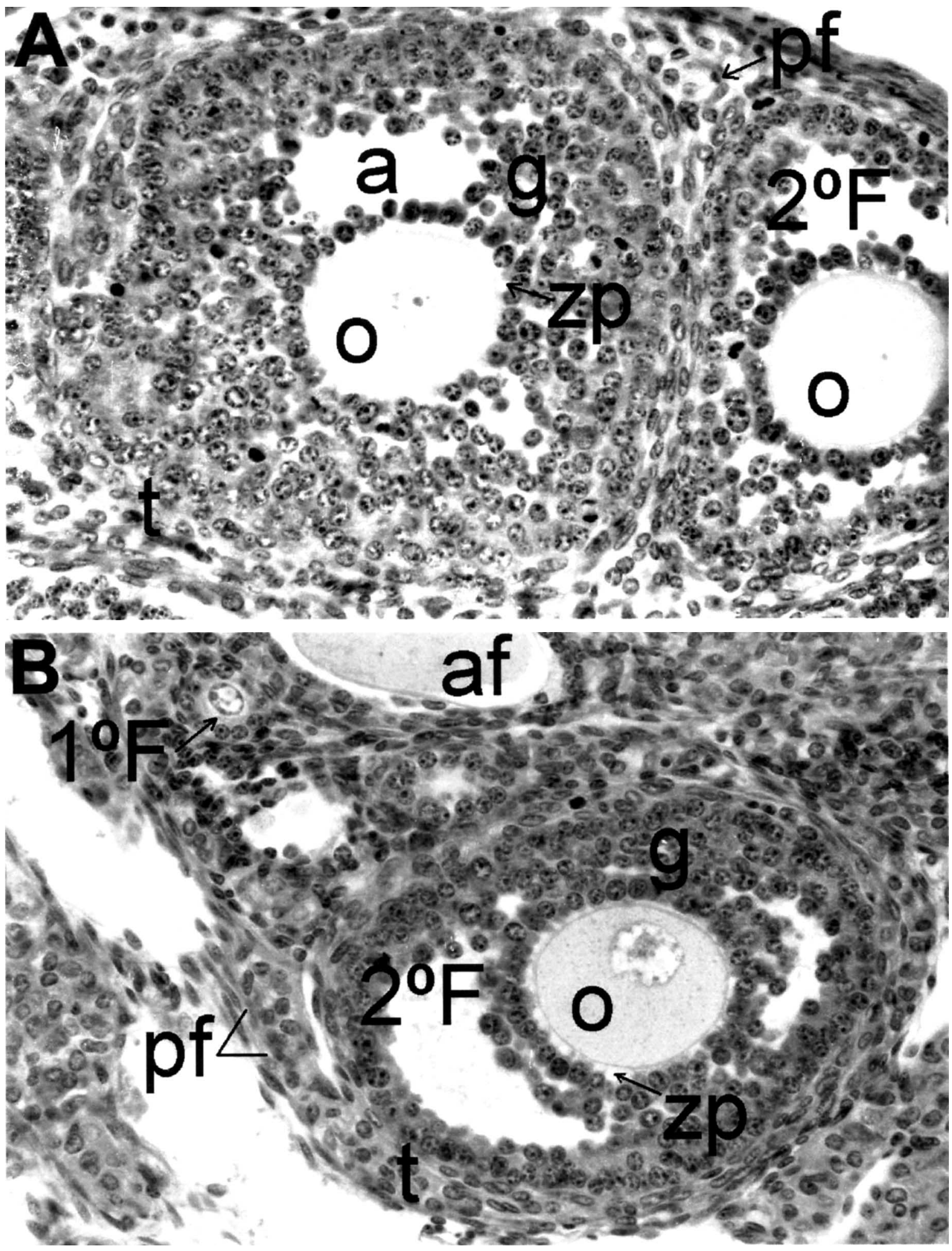

Fig. 1. Healthy follicles of control (A) and FNZ (B) groups show normal appearance. Primordial follicles (pf) primary follicles $\left(1^{\circ} \mathrm{F}\right)$, secondary follicles $\left(2^{\circ} \mathrm{F}\right)$; granulose cells $(\mathrm{g})$, oocyte (o), thecal cells (t), zona pellucida (zp), antrum (a), and atretic follicle (af). Original magnification 40X. 

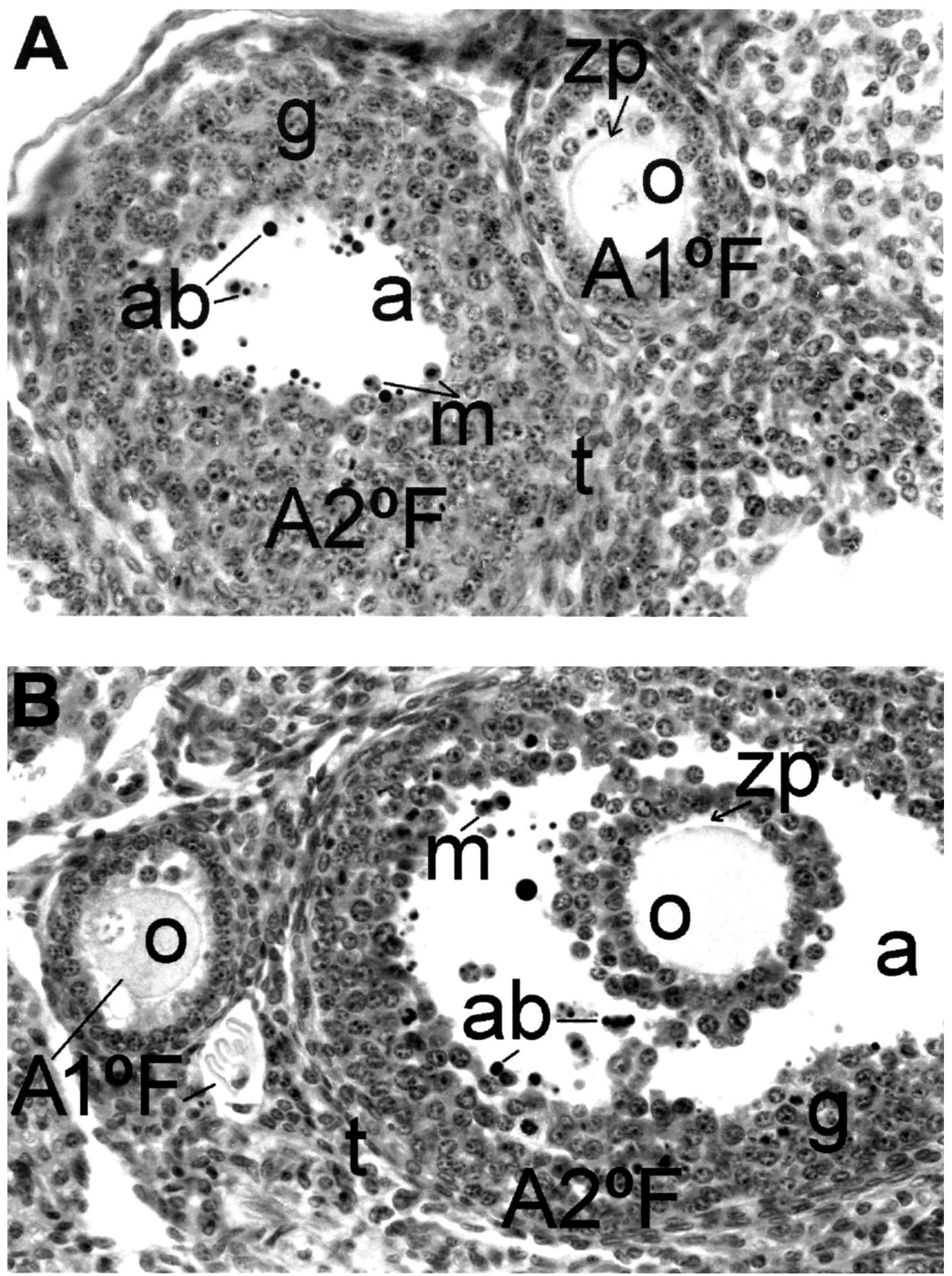

Fig. 2. Atretic follicle of control (A) and FNZ (B) groups shows altered appearance with staining affinity. Atretic primary follicle $\left(\mathrm{A} 1^{\circ} \mathrm{F}\right)$, atretic secondary follicles $\left(\mathrm{A} 2^{\circ} \mathrm{F}\right)$. Both panels: granulose cells $(\mathrm{g})$, oocyte $(\mathrm{o})$, the calcells (t), zona pellucida (zp), antrum (a), apoptotic bodies (ab), and macrophages (m). Original magnification, 40X. 



Fig. 3. Sections of corpus luteum of control (A) and FNZ (B) ovaries, showing normalor abnormal granulose luteal cells (gl) and thecal luteal cells (tl), respectively. Original magnification 100X. 

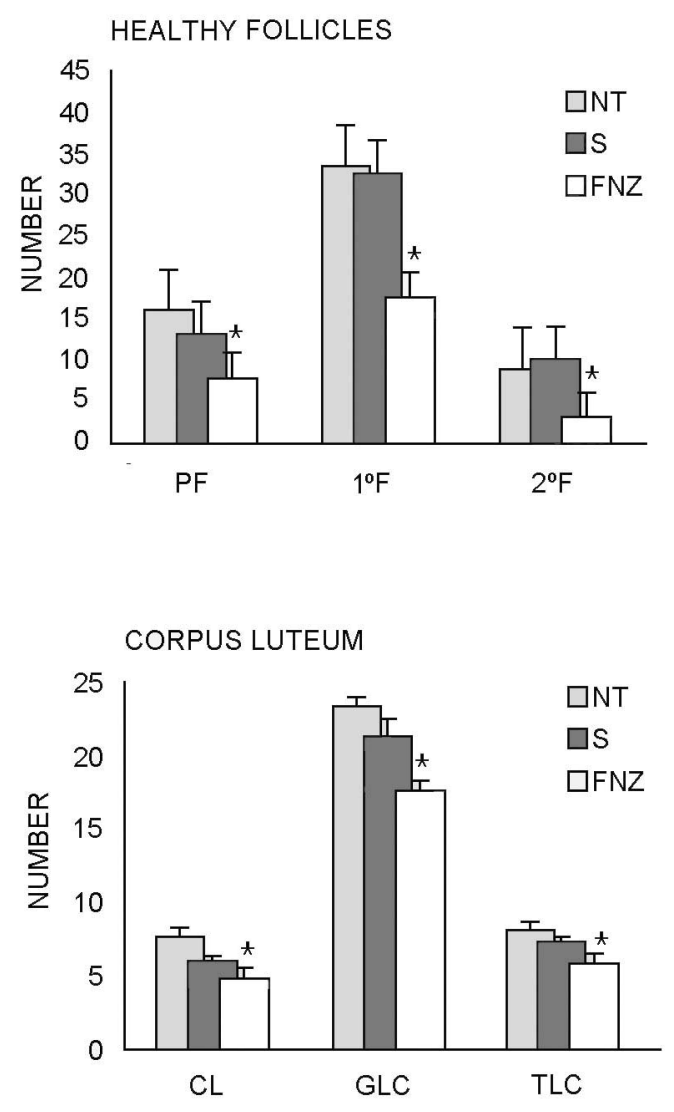

\section{DISCUSSION}

To our knowledge, the histological changes in the adult ovary of mice exposed to FNZ during the embryonic period have not been described yet in the pertinent medical literature. FNZ administration at GD 6, as practiced in this study, could be altering the totipotent cells in the active phase of cellular division when implantation starts, in mice (Biskov, 1978). This study indicates that FNZ administered in utero alters growth and development of the ovarian follicles in mice. The high staining affinity of the nuclei and of the clumps could be due to an apparent increase in heterochromatin.

The statistically significant increase in the number of atretic follicles could be due to FNZ exposure during gestation. RBC is associated with GABA and PBR (Braestrup \& Squire, 1977), which appear early during embryonic development (Anholt et al., 1985, Hebebrand et al., 1988), the start of FNZ administration in gestating mice. The cell toxicity process generated by BDZ could involve the ontogenic PBR development. The ligand of this proteic complex (McEnery et al., 1992), lets cholesterol cross the

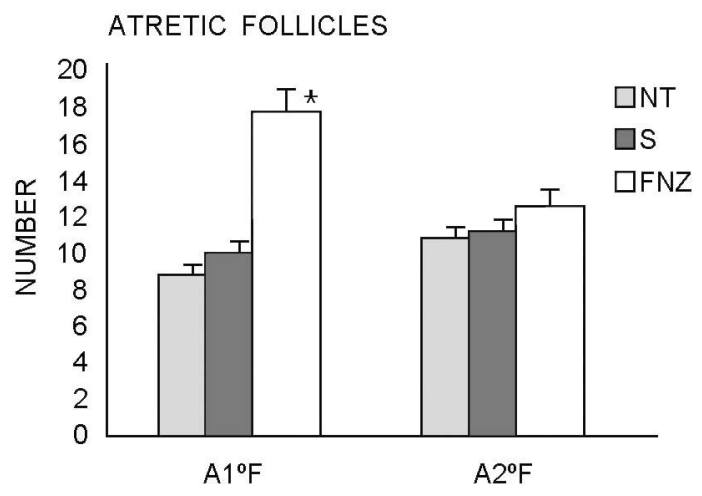

Fig. 4. Follicles and corpus luteum of the ovary of control groups [non-treated (NT) and saline solution (S)] and the flunitrazepam group (FNZ). Healthy follicles (A), atretic follicles (B), and corpus luteum (C). Primordial follicles (PF), primary follicles $\left(1^{\circ} \mathrm{F}\right)$, secondary follicles $\left(2^{\circ} \mathrm{F}\right)$, atretic primary follicles $\left(\mathrm{A} 1^{\circ} \mathrm{F}\right)$, atretic secondary follicles $\left(\mathrm{A} 2^{\circ} \mathrm{F}\right)$, total number of corpus luteum $(\mathrm{CL})$, granulose luteal cells (GLC), and thecal luteal cells (TLC). $*$ Significant difference $(\mathrm{p}<0.05)$. outer membrane of mitochondria (Papadopoulos et al., 1991, 1997), leading to progesterone biotransformation by ovarian cells, suprarenal glands, SNC (Parola et al.), and placenta (Barnea et al., 1989). If FNZ increased steroid concentration this would induce a physiologic imbalance in the ovarypituitary-hypothalamic axis and would inhibit GnRH, LH, and FSH secretion. These hormones are necessary to induce steroid synthesis in the ovary. In consequence, this increase possibly causes theca and granulosa cells hypertrophy, changing the follicular morphology and physiology, resulting in probable apoptosis (Wyllie et al., 1980). Sinha-Hikim et al. (1997), confirmed the effects of absent hyphophyseal hormones in the ovary of adult rats, which raised the apoptotic cell proportion.

Furthermore, all long lasting toxic events induced by FNZ in mouse offsprings could be associated with changes in gene expression, and chromatin plays a pivotal role in its regulation. In these toxic events, the indirect increase of estrogens, as xenobiotics, and as target in nuclear receptor could elicit perturbation of chromatin integrity, and this 
process presents factors that may function as markers of toxicity, such as the histone H2A.X., which occurs during apoptosis and involves chromatin condensation, a step that precedes DNA fragmentation (reviewed by Moggs J, Orphanides, 2004). These events, although not tested with a direct apoptotic analysis in this work, were observed in the treated tissue as apoptotic bodies.

In conclusion, the effects of FNZ administered prenatally to ICR mice induce a significant reduction in healthy follicles, corpus luteum, luteal cells, paraluteal cells, and produce an increase in primary atretic follicles as compared to the control groups. The results suggest that FNZ during gestation could have a toxic effect and play an important role in growth and development of follicles and luteal cell populations.

\section{ACKNOWLEDGMENTS}

The authors gratefully acknowledge Enrique Wintergerst Toledo, MD, for academic assistance and review of the manuscript and Dr. Mario Casares for his suggestions.

AGUIRRE-SAMUdio, A. J.; DE LA FUENTE-JUÁREZ, G.; MÁRQUEZ-OROZCO, A. \& MÁRQUEZ-OROZCO, M. C. Cambios histológicos del ovario de ratones adultos expuestos prenatalmente a flunitrazepam. Int. J. Morphol., 24(4):651-658, 2006.

RESUMEN: El flunitrazepam (FNZ) es un tranquilizante menor que actúa modulando el receptor GABA, es un ligando del receptor benzodiazepínico periférico (PBR), el cual participa en el transporte de colesterol en órganos esteroidogénicos. El objetivo de este trabajo fue investigar si una dosis oral de FNZ $(2.5 \mathrm{mg} / \mathrm{kg}$ de peso) administrada en el sexto día de gestación, altera la estructura del ovario en crías de ratón adultos. Las crías del grupo FNZ tratadas in utero con la benzodiazepina, así como el grupo control, fueron sacrificadas. Los ovarios se extrajeron en estro temprano, se fijaron en líquido de Zenker y procesaron con las técnicas habituales de histología. Los cortes seriados fueron analizados mediante microscopia óptica, los folículos fueron identificados y contados de acuerdo a los diferentes estadios del desarrollo, así como las células del cuerpo lúteo. El tejido ovárico en el grupo de FNZ presentó una gran afinidad tintórea, núcleos grandes y con abundantes cúmulos de heterocromatina. El número de folículos primordiales, primarios y secundarios en el grupo FNZ disminuyó ( $\mathrm{p}<0.01)$. Contrario al número de folículos atrésicos que aumentaron $(\mathrm{p}<0.01)$, a excepción de los folículos atrésicos secundarios que no fueron diferentes a los controles. Las alteraciones histológicas y los datos estadísticos sugieren que el FNZ produce un efecto epigenético o genotóxico de largo plazo tanto en los folículos como en las células del cuerpo lúteo, de ratones tratados prenatalmente con el fármaco.

PALABRAS CLAVE: Benzodiazepinas; Flunitrazepam; Folículos atrésicos; Cuerpo lúteo; Exposición prenatal.

\section{REFERENCES}

Andrè, M.; Sibout, M.; Petry, J-M. \& Vert, P. Déepression respiratoire et neurologique chez le premature nouveauné de mére traitèe per diazepam. J. Gyn. Obst. Biol. Reprod., 2:357-66, 1973.

Anholt, R. R.; De Souza, E.; Oster-Granite, M. L. \& Snyder, S. H. Peripheral-type benzodiazepine receptor: auto radiographic localization in whole-body sections of neonatal rats. J. Pharmacol. Exp. Ther., 233:517-26, 1985.

Barnea, E. R.; Fares, F. \& Gavich, M. Modulator action of benzodiazepines on human term placental steroidogenesis in vitro. Moll. Cell. Endocrinol., 64:1559, 1989 .

Braestrup, C. \& Squire, R. F. Specific benzodiazepine receptors in rat brain by high-affinity $[3 \mathrm{H}]$ diazepam binding. Proc. Natl. Acad. Sci. U.S.A., 74:3805-09, 1977.
Byskov, A. G. Follicular atretia. In: The vertebrate ovary, NY, Plenum Press, New York, 1978.

De La Fuente-Juárez, G.; Márquez-Orozco, M. C. \& Márquez-Orozco A. Persistent alterations in ossification in adult mice prenatally treated with Diazepam. Proc. West Pharmacol. Soc., 41:187-8, 1998.

File, S. The history of benzodiazepine dependence: a review of animal studies. Neuroscience \& Biobehavioral Rev., 14:135-46, 1990.

Hebebrand, J.; Hofmann, D.; Reichelt, R.; Schnarr, S.; Knapp, M.; Propping, P. \& Fodisch, H. J. Early ontogeny of the central benzodiazepine receptor in human embryos and fetuses. Life Sci., 43:2127-36, 1988.

Hernández-Alvarez, L.; Márquez-Orozco, M. \& Márquez Orozco, A. Effects of prenatal administration of diazepam on the ovary of mice. Proc. West. Pharmacol. Soc., 34: 379-82, 1991. 
Jolly, P. D.; Smith, P. R.; Heath, D. A.; Hudson, N. L.; Lun, S.; Still, L. A.; Watts, C. H. \& McNatty, K. P. Morphological evidence of apoptosis and the prevalence of apoptotic versus mitotic cells in the membrane granulosa of ovarian follicles during spontaneous and induced atretia in ewes. Biol. of Reprod., 56:837-46, 1997.

Kanto, J. H. Use of benzodiazepine during pregnancy, labor and lactation, with particular reference to pharmacokinetic considerations. Drugs, 23:354-80, 1982.

Kanto, J.; Erkkola, R.; Kangas, L. \& Pitkänen, Y. Placental transfer of flunitrazepam following intramuscularly administration during labor. Br. J. Clin. Pharmacol., 23: 491-4, 1987.

Laegreid, L.; Olegard, R.; Walströn, J. \& Conradi, N. Teratogenic effects of benzodiazepine use during pregnancy. J. Pediat., 114:126-31, 1989.

Márquez-Orozco, A.; Márquez-Orozco, M. C. \& GazcaRamírez, M. V. Effects of diazepam on the ultrastructure of fetal mice hepatocytes. Proc. West. Pharmacol. Soc., 36:113-6, 1993.

Márquez-Orozco, M. C.; Márquez-Orozco, A. \& SámanoBishop, A. Efecto del diazepam (valium) en riñones fetales in vivo. Bol. Soc. Mex. Cienc. Fisiol., 7:16-20, 1984.

Márquez-Orozco, M. C.; Márquez-Orozco, A.; De la Fuente-Juárez G., \& Hernández-Alvarez, L. A. Long-lasting effects of prenatal exposure to diazepam in mesencephalon of mice. Proc. West. Pharmacol. Soc., 41:189-91, 1998.

Mata-Santibañez, M. V.; Márquez-Orozco, A, \& MárquezOrozco, M. C. Testicular histological changes in mice after prenatal administration of diazepam. Proc. West Pharmacol. Soc., 36:117-21, 1993.

McAllister, C. B. Placental transfer and neonatal effects of diazepam when administered to women just before delivery. J. Anesth., 52:423-7, 1980.

McEnery, M.; Snowman, A.; Trifiletti, R. \& Snyder S. Isolation of the mitochondrial benzodiazepine receptor: Association with the voltage-dependent anion channel and the adenine nucleotide carrier. Proc. Natl. Acad. Sci. USA, 89:3170-4, 1992.
Moggs, J. \& Orphanides, G. The role of chromatin in molecular mechanisms of toxicity. Toxicological Scii., 80:218-24, 2004.

Mukhin, A.; Papadopoulos, V.; Costa, E. \& Krueger K. Mitochondrial benzodiazepine receptors regulate steroid biosynthesis. Proc. Natl. Acad. Sci. USA, 86:9813-6, 1989.

Papadopoulos, V.; Amri, H.; Li, H.; Boujrad, N.; Vidic, B. \& Garnier, M. Targeted disruption of the peripheral-type benzodiazepine receptor gene inhibits steroidogenesis in the R2C Leydig tumor cell line. J. Biochem. Chem., 252:32129-35, 1997.

Papadopoulos, V.; Nowzari, F. \& Krueger, K. Hormonestimulated steroidogenesis is coupled to mitochondrial benzodiazepine receptors. J. Biochem. Chem., 266: 36827, 1991.

Parola, A.; Yamamura, H. \& Laird, II H. Peripheral-type benzodiazepine receptors. Life Sci., 52:1329-42, 1993.

Sinha Hikim, A.; Rajavashisth, T.; Sinha Hikim I.; Lue Y.; Bonavera, J.; Leung, A.; Wang, C. \& Swerdloff, R. Significance of apoptosis in the temporal and stagespecific loss of germ cells in the adult rat after gonadotropin deprivation. Biol. Reprod., 57:1193-201, 1997.

Wyllie, A.; Kerr, J. \& Currie, A. Cell death: the significance of apoptosis. Int. Rev. Cytol., 68:251-305, 1980.

Zisterer, D. \& Williams, D.C. Peripheral-type benzodiazepine receptors. Gen. Pharmacol., 29:305-14, 1997.

Correspondence to:

Dra. María Cristina Márquez Orozco

Departamento de Embriología

Facultad de Medicina

Universidad Nacional Autónoma de México (U.N. N.P.M.)

$\mathcal{M}$ éxico 04510 D. F.

MÉXICO

Tel. (52-55) 5623-2353, Fax (52-55) 5623-2156

email:cmarquez@servidor.unam.mx

Received: 14-06-2006

Accepted: 25-10-2006 